\title{
透析患者における酸塩基平衡の特殊性 一スペクトル解析の立場よりー
}

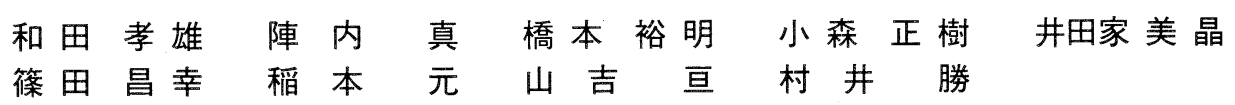

慶応大学腎臓センター

(昭和 60 年 9 月 28 日受付)

key words：酸塩基平衡，ホメオスターシス，貧血，スペクトル解析

〈要旨〉

透析患者の酸塩基平衡の特殊性を明らかにするために, 新しい統計学的手法であるスペクトル解析法を用いて研究 を行った，㫕の結果，透析患者の血液ガスおよび重炭酸の変化には，蛋白・アミノ酸の代謝をはじめとするきわめて 多因子が影響を及ぼしている事が明らかにされた。 また電解質の変動は, 乥れ自体としてはあまり直接的な因子とは 考えられず，むしろ他の代謝網の変動を介する間接的なものが主である可能性が示唆された。 またインパルス応答の 結果により，代謝性アシドーシスが賓血や血圧に対しても影響するという成績が得られた。

\section{Peculiarities of acid-base balance in hemodialysis patients from the point of view of spectral analysis}

Takao Wada, M. D., Makoto Jinnouchi, Hiroaki Hasimoto, Masaki Komori, Yosiaki Itaya, M. D., Masayuki Shinoda, M. D., Hajime Inamoto, M. D., Wataru Yamayoshi, M. D. and Masaru Murai, M. D. Kideny Center, Keio University Hospital

In order to investigate the peculiarities of acid-base balance in hemodialysis patients, a new statistical method, an autoregressive approach to spectral analysis, was adopted. It was found that the multivariate feedback system is involved in the regulation of acid-base balance in hemodialysis patients. Major factors for inducing metabolic acidosis in these patients included the protein and the amino acid metabolisms. Although electrolyte metabolism is also involved in the regulation of acid-base balance in these patients, its role seemed to be secondary to those of other intracellular metabolisms. Analysis with impulse response function strongly suggested that metabolic acidosis can become a trigger of anemia and hypertension in these patients.

\section{緒言}

透析患者において，酸塩基平衡が重要な役割を演じて いることは推察に難くないが，それが患者の代謝機能に どう影響しているかという事になると, 不明な点が多い. そこで, 今回の研究では, スペクトル解析法という全 く新しい手法を用いてこの問題に取り組んだ。この解析 法は赤池がセメントキルンのコンピュータ制御に用い て, 大きな成功をおさめたもので ${ }^{1 \sim 3)}$, これを和田, 赤池 らが生体内の代謝のネットワークに利用し得る事を明ら かにしたものである ${ }^{4 \sim 7}$.

方法

慶応大学病院腎臓センターに通院中の慢性透析患者の

和田 孝雄 慶応大学別館腎臟センター

₹ 160 新宿区信濃町 $35(03-353-1211)$
$7 〜 10$ 年間にわたる血液デー夕に関して，自己回帰モデ ルを用いてスペクトル解析を行った。

自己回帰モデルを用いたスペクトル解析法の原理を以 下に示す。

まず，自己回帰モデルの基本的な式は次のごとくであ る.

$$
\mathrm{X}(\mathrm{S})=\Sigma \mathrm{a}(\mathrm{m}) \mathrm{X}(\mathrm{s}-\mathrm{m})+\mathrm{n}(\mathrm{s})
$$

この式の意味は, ある変数の現在值はその変数の過去 の值の線形結合および確率雑音との総和によって表され るという事である.

これを多変量フィードバック系にあてはめるために赤 池が考案した式が次のようなものである. 


$$
\begin{aligned}
& X_{i}(s)=\sum_{m=1 j}^{M} \sum_{j=1}^{K} a_{i j}(m) X_{j}(s-m)+n_{i}(s) \\
&(i=1,2, \cdots K)
\end{aligned}
$$

この式における係数 $\mathrm{a}_{\mathrm{ij}}(\mathrm{m})$ は最少自乗法を用いて求 める事ができる。そのためには残査部分 $n_{i}(s)$ の自乗值 の $\mathrm{a}(\mathrm{m})$ に関する偏微分がゼロとなることが要求され る。そこで以下の式が成り立つ。

$$
\frac{\partial}{\partial a_{i j}(m)}\left(X_{i}(s)-\sum_{m=1}^{M} \sum_{j=1}^{K} a_{i j} X_{j}(s-m)^{2}=0\right.
$$$$
(\mathrm{i}=1,2, \cdots \mathrm{K})
$$

この結果，次のごとき Yule Walkerの式が得られる.

$$
\begin{aligned}
& \sum_{m=1 j}^{M} \sum_{j=1}^{K} a_{i j}(s) R_{j h}(s-m)=R_{j h}(s), \\
&(i, h=1,2 \cdots, k ; s=1,2, \cdots, M)
\end{aligned}
$$

ここで $R_{\mathrm{jh}}$ は以下のごとく $\mathrm{X}_{\mathrm{j}}(\mathrm{s})$ と $\mathrm{X}_{\mathrm{h}}(\mathrm{s})$ の共分散で ある。

$$
R_{\mathrm{jh}}(\mathrm{m})=1 / \mathrm{N} \sum_{\mathrm{s}=1}^{\mathrm{N}-\mathrm{m}} \mathrm{x}_{\mathrm{j}}(\mathrm{s}+\mathrm{m}) \mathrm{x}_{\mathrm{h}}(\mathrm{s})
$$

上記 Yule Walkerの式を解くことによって $\mathrm{a}_{\mathrm{ij}}(\mathrm{m})$ が 得られ，それをフーリ工変換することによって $\mathrm{a}_{\mathrm{ij}}(\mathrm{f})$ が 得られる。

$$
a_{i j}(f)=\sum_{m=1}^{M} a_{i j}(m) e^{-2 \pi f m(\operatorname{SQRT}(-1))}
$$

$a_{i j}$ (f) の行列 $A(f)$ と, 残査部分の共分散行列 $\left(\mathrm{s}_{\mathrm{ij}}\right)$ を

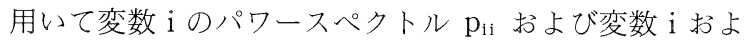
び $\mathrm{j}$ 間のクロススペクトル $\mathrm{q}_{\mathrm{ij}}$ が得られる。

$$
\begin{aligned}
P(f) & =\left(p_{i j}(f)\right) \\
& =(A(f))^{-1}\left(s_{i j}\right)\left(A(f)^{T}\right)^{-1}
\end{aligned}
$$

$\mathrm{n}_{\mathrm{j}}$ と $\mathrm{n}_{\mathrm{i}}$ の間の相関がゼロであると仮定すると $\mathrm{s}_{\mathrm{ij}}$ はゼ ロと見なせるから，パワースペクトル $\mathrm{p}_{\mathrm{ij}}$ は以下のごと く簡略化される。

$$
p_{i 1}(f)=\sum_{j=1}^{K} q_{i j}(f)=\sum_{j=1}^{K}\left(a_{i j}(f)^{-1}\right){ }^{2} S_{j j}{ }^{2}
$$

ここでクロススペクトル $\mathrm{q}_{\mathrm{ij}}$ は以下のごとく表現され る。

$$
q_{i j}(f)=\left(a_{i j}(f)^{-1}\right){ }^{2} S_{j j}{ }^{2}
$$

この $\mathrm{p}_{\mathrm{ii}}$ と $\mathrm{q}_{\mathrm{ij}}$ の比， $\mathrm{r}_{\mathrm{ij}}$ がパワー寄与率と呼ばれるも のである。

$$
r_{i j}(f)=\frac{q_{i j}(f)}{p_{i j}(f)}
$$

このパワー寄与率はある変数の変動のパワースペクト ルに対して他の変数からのクロススペクトルがいかなる 割合で寄与してるかという程度を表す。なおこの計算過 程の詳細に関しては文献 2 ）を参照されたい。

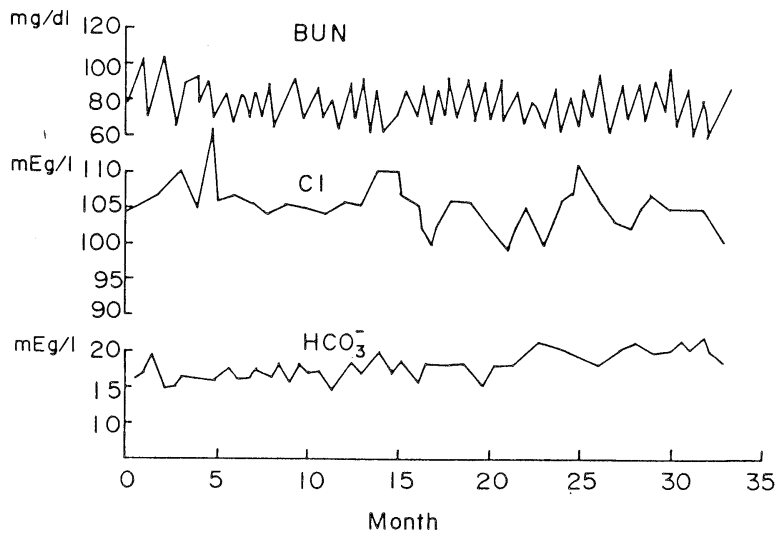

図 1 透析患者の検査デー夕における時系列的変化

\section{結果}

図 1 にはある症例の $\mathrm{BUN}$, 血清 $\mathrm{Cl}$, 血清重炭酸の時系 列的変化を示した。これに見るごとく，三者は時間のず れを伴ってある種の相関関係を保ちながら，上昇，下降 を繰り返している。これらの変動は速い動き, 遅い動き とまざりあった複雑な合成波となっている。そこでこれ らを単純なサインカーブからなる各コンポーネントに分 解し，そのコンポーネント同志の相互関係を調べること とする。

図 2 は同症例の血清重炭酸濃度の時系列的変化に対し て，各種臨床パラメータのスペクトルがどの程度寄与し ているかを，パワー寄与率の面から調べたものである。 この図において，X軸はその各コンポーネントの周波数 を示す。単位は cycle/week となっている。

また Y 軸は血清重炭酸の変動スペクトルを 1 とした場 合における，各パラメータのスペクトルの寄与率を累積 的に示したものである。したがって，累積合計は 1.0 と なるが，各パラメータの累積によって説明されない不足 分は, 血清重炭酸自身の固有な変動分として表現される ことになる。

この図に見るごとく，0.1 cycle/week の周波数におい て, 各パラメータの笴与率の累積が約 7 割に達しており, 約 10 週に 1 度ぐらいの動きが代謝過程において, 重要な 役割を演じていることがわかる。また，この累積部分の 内容を検討してみると, $\mathrm{Cl}, \mathrm{K}, \mathrm{Mg}, \mathrm{P}$ などの血清電解質 の寄与はあまり高くはなく，むしろより有機質の代謝が 重要な寄与を行っていると考えられる。ことにガンマ GTP, LAP, GOT などの寄与率の高いのは, おそらくア ミノ酸の代謝などが, 重炭酸の動きに重要な役割を演じ ていることを示唆するものである.

図 3,4 には $\mathrm{PCO}_{2}, \mathrm{Po}_{2}$ の変動に対する各種パラメー 夕の寄与の度合を示す. $\mathrm{PCO}_{2}$ の場合には, 累積寄与率が 


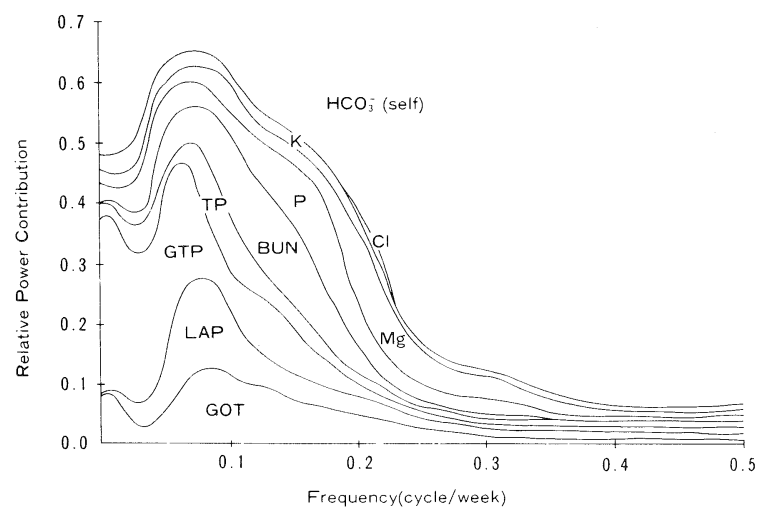

図 2 透析患者の血清重炭酸濃度変化に対する各種臨床 パラメータのパワー寄与率

あまり高くなくこれらの代謝網によってはその変動を 必ずしもうまく説明できないことがわかった。これに対 して, $\mathrm{Po}_{2}$ の変動は比較的によく代謝網の変動によって 説明される。

さてこれらの事から考えて，蛋白やアミノ酸の代謝を 含む多因子が代謝性アシドーシスの発生に関与している 事がわかったが，これが，実際に患者の健康状態にどう 影響するかを知ることが必要となる。そこで赤池モデル を用いて得られた自己回帰係数行列からインパルス応答 関数を算出した。

図 5 は重炭酸濃度の変化をインパルスとして, 入力し た場合の系の応答を図示したものである。このインパル スは高さが無限大で，幅はゼロ，積分すると 1 になるよ うなものとして定義されている。これを入力すると，血 液のへモグロビン濃度は $3 \sim 4$ 日ぐらい低下し, 約 1 週 間で回復し，その後オーバーシュートしてもとにもどる までに約 20 週ぐらいを要する。

図 6 は同じく重炭酸濃度のインパルスに対して，血圧 がいかに応答するかを見たものである。この場合には， 血圧がいったん 1 週間ぐらい下降し，4 週間ぐらいでも とにもどる。

これらの事から考えて, 代謝性アシドーシスの程度は, あきらかに生体内の代謝システムに大きな影響を与えて いることはまちがいないと考えられる。

\section{考察}

赤池の自己回帰モデルを用いて生体内のホメオスター シスを解析する試みは, ごく最近，和田，赤池らによっ て行われたものである ${ }^{4 \sim 7)}$.これによって, 従来の方法で は不可能であった生体内のネットワーク解析が可能と なった。

本研究では，この手法を用いて透析患者の酸塩基平衡 が，患者の健康維持にいかに関与しているかを知る手懸

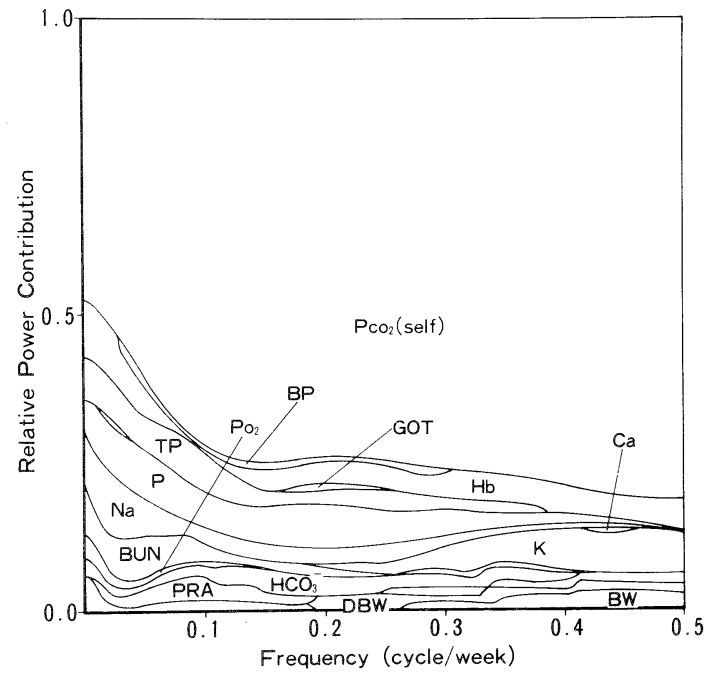

図 3 透析患者の血液炭酸ガス濃度の変化に対する各種 臨床パラメータのパワー寄与率

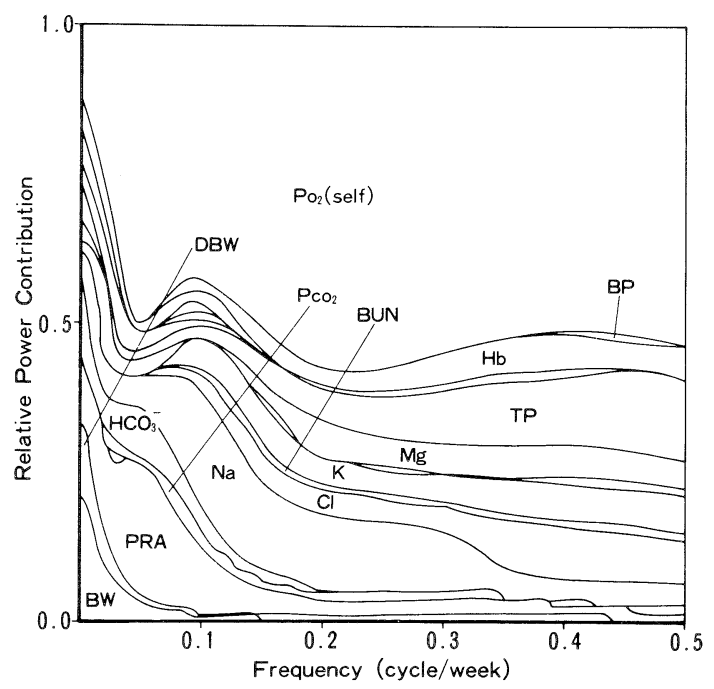

図 4 透析患者の血液酸素濃度の変化に対する各種臨床 パラメータのパワー寄与率

かりが得られた。

研究結果によ机ば，透析患者の代謝性アシドーシスが 非常に多くの因子のネットワークの動きによってもたら されている事が明らかである，特に，血清の電解質より は，蛋白・アミノ酸の代謝によって大きな影響をうけて いる可能性が示唆された。もっともそれだからといって, $\mathrm{K}, \mathrm{Mg}, \mathrm{P}$ などの細胞内イオンの動向が重要でないとは いえない.ただこ机らのイオンが血清内の動きから推察 するかぎりに扔いては，直接的に大きな役割を演じてい るという証拠が得られなかったにすぎない。しかし，細 胞内外の水素イオンの出入りに対して，これらのイオン 


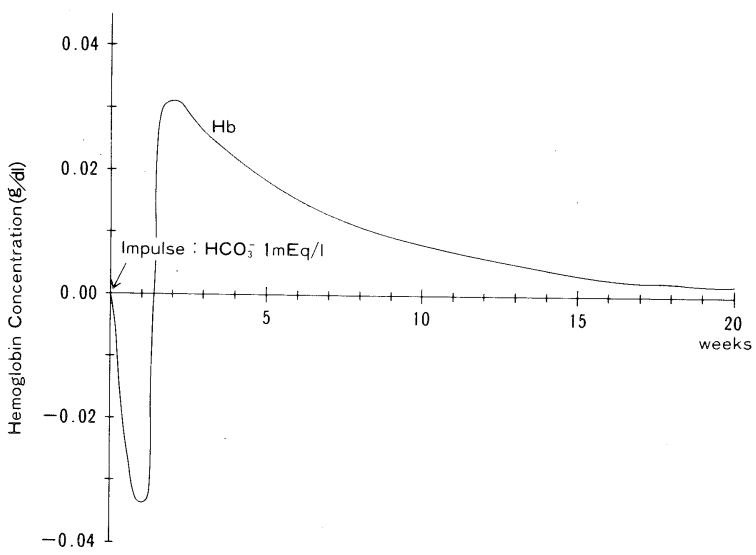

図 5 重炭酸濃度の変化に対する血液へモグロビン濃度 のインパルス応答

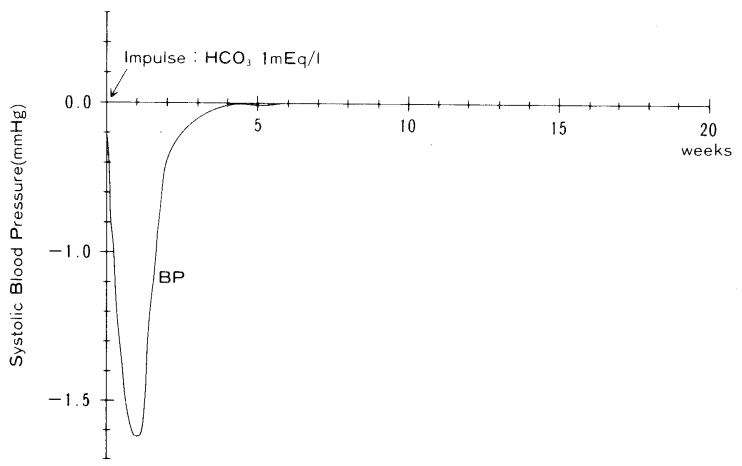

図 6 重炭酸濃度の変化に対する血圧のインパルス応答

は重要な影響を与えると思われるので, 蛋白やアミノ酸 の代謝などを介して，少なくとも間接的な役割を演じて いる可能性は否定できない。

この点を確認するために, 我々は現在いろいろなパラ メータを系に加えたり，外したりすることによる累積寄 与率の変化を検討中である。その予備的成績もほぼ上記 の説明に合致している.

さて, 今回の成績でもっともユニークなものは, イン パルス応答の結果である。それによれば,代謝性アシドー シスは貧血や高血圧の原因となる可能性が示唆された.
実際, 血清重炭酸を変化させた時に, 生体がどう反応す るかを明らかにした研究報告はほとんどない。もし重炭 酸を与えたとしても, $\mathrm{Na}$ 投与の影響も生じるため,これ を直接的に確かめることは大変むずかしい.したがって， 我々の成績も現時点では仮説にとどまらざるを得ない. しかし，このような数学的手法の妥当性が次第に確認さ れしかも各種の知見が積みかさねられるにしたがって, この問題も解決に近付くと思われる。この点に関して, 現在我々が小児科領域の研究者と共同で進めている酸塩 基平衡のスペクトル解析の成績の有用性が期待される。

\section{文献}

1) Akaike, H. : Some problems in the application of the cross-spectral method. In Spectral Analysis of Time Series, B. Harris, editor, John Wiley, New York, 1967, p 81-107.

2) Akaike, H. : On the use of a linear model for the identification of feedback systems. Ann. Inst. Statist. Math. 20 : 425-439, 1968.

3) Akaike, H. : Information theory and an extention of the maximum likelihood principle, Proc. 2nd Int. Symp. on Information Theory (Petrov, B. N. and Csaki, F. eds.), Akademiai Kiado, Budapest, 1973, p 267-281.

4) Wada, T., Akaike, H., and Kato, E. : Autoregressive models provide stochastic descriptions of homeostatic processes in the body. Jap. J. Nephrol. In press.

5) Wada, T., Akaike, H : Frequency dependency of causal favtors for hypertension in hemodialysis patients. submitted for publication.

6）和田孝雄, 安達 直：免疫修飾剂によって惹起され た脾臓内代謝網の振動とその解析. 医用電子の生体 工学 22 (特別号) : 862-863，1984.

7）和田孝雄：ある透析症例のアシドーシスに関するス ペクトル解析。臨床体液 $12: 57-60,1985$. 